\title{
18
}

\section{Waiting for Spider-Man: Representations of Urban School "Reform" in Marvel Comics' Miles Morales Series}

\author{
David E. Low
}

\section{Charter Schools in Children's Media}

In the spring of 2012, the Scantron Corporation was criticized by an activist group in Chicago for including items on a standardized test that exposed an audience of public school students to pro-charter school propaganda. Julie Woestehof, executive director of Parents United for Responsible Education, indicated that the reading comprehension passages, which Scantron claimed were designed to test the "critical thinking skills of seventh-grade-level students," were so biased in favor of charter schools that the test's use amounted to an attempt to brainwash the thousands of students who took the test over two years in over 600 schools (Rossi). Written in a nonfiction style, the passage stated that charter schools are "open to all students," that they are "showing improvements in student achievement," and that the fictitious children of a fictitious multimillionaire attend a charter school because their father "believes that charter schools deliver the highest quality education" (Hyde Park Johnny). During PURE's dispute with Scantron, Woestehoff wrote that "students taking a test should not be subjected to false claims about charter schools which could cause them to feel humiliated, second-class, or dumb because they do not attend a 'better' charter school... . They are brainwashing our kids to make them think they should be in a charter school" (quoted in Rossi). Scantron ultimately dropped the passage from future tests and issued an apology.

In the United States, debates about school "reform" in the twenty-first century have been frequent, divisive, and well-covered in mainstream media intended for an adult audience. It is important to note that even when this politically and ideologically charged issue appears lopsided depending on the leanings of a particular media outlet, in the world of adult-geared media, 
there are typically opportunities to encounter a range of counterpoints. As evidenced by the Scantron incident, however, these opportunities do not as often exist in media intended for young people. After a thorough search, I was able to locate only a few examples of children's media (one novel, one comic book series, and one issue of Time Magazine for Kids ${ }^{1}$ ) in which charter schools are treated as a pertinent topic. The near invisibility of an issue that is salient to the lives of so many young people begs the question: when it appears at all, how is school "reform" represented in media intended for children and youth, and what narratives around this complex issue are coming to the fore?

This chapter examines representations of an urban charter school lottery in Marvel's Ultimate Comics Spider-Man (Bendis and Pichelli), a comic book series that is popular with young readers, regularly selling 35,000 to 50,000 single issues in a month, and considerably more once anthologized in hard and softcover editions (Fraser). ${ }^{2}$ The critically acclaimed title, which began in September 2011, features Miles Morales, a young Afro-Latino protagonist from a working-class community in Brooklyn, who takes on the iconic role of Spider-Man. Since the title's launch, Miles has proven especially popular with readers from racial and ethnic minority groups who have felt under- and misrepresented in mainstream superhero comics (see Cavna; Foster; Nama). For some fans, Miles functions as a cypher for young Black masculinity within print and other visual media (Fu; McWilliams). Indeed, when I asked a group of Black fifth-grade participants in my Philadelphia-based research project (see Low and Campano for an overview of the project) which actor they imagined playing Miles in a hypothetical movie adaptation, several of the boys emphatically replied, "Me!!!” Miles is, by a wide margin, the comic book character with whom my male students (grades $4-8$ in an urban Catholic school) most claim to identify. In the series's first issue, Miles is bitten by a radioactive spider and endowed with the superpowers of Peter Parker, the original (and recently deceased) Spider-Man. Miles also gains the not-so-subtly symbolic ability to turn invisible. Much of the subsequent series focuses on Miles learning to balance his new existence, including fighting crime, attending to family obligations, and beginning school at the Brooklyn Visions Academy, an urban charter school outside his immediate neighborhood. In the series's first issue, Miles wins a lottery to attend the school. It is this three-page sequence on which this chapter will focus.

\section{Critical Multicultural and Multimodal Analysis}

Marjorie Siegel and Carolyn P. Panofsky write, "There is no ready-made toolkit for analyzing multimodal [texts]," so "researchers have turned to a range of theories ... which can be productively blended" (101). For the purpose of this 
chapter, I blend critical multicultural analysis of children's literature (Botelho and Rudman) with forms of critical visual analysis (Aiello; Connors; Schieble) in order to examine how urban education "reform" is represented in Marvel's Ultimate Comics Spider-Man. I also use terms from comics and multimodalities researchers to assist in my visual analysis.

Critical multicultural analysis of children's literature (CMA), an approach advanced by Maria José Botelho and Masha Kabakow Rudman, maintains that because all literature is an historical product, it is inscribed at multiple levels with implicit and explicit ideologies - "a product of culture as well as evidence of power relationships" (72). This is true even, and perhaps especially, of ideologies that are not deliberately invoked by authors. As Robert D. Sutherland contends,

Works written especially for children are informed and shaped by the authors' respective value systems, their notions of how the world is or ought to be... To publish books which express one's ideology is in essence to promulgate one's values. To promulgate one's values by sending a potentially influential book into public arenas already bristling with divergent, competing, and sometimes violently opposed ideologies is a political act. (143)

Employing CMA as an analytic framework attempts to surface the ideological and political underpinnings of authored texts, particularly as they relate to the institutional organization of knowledge and power along raced, classed, and gendered lines. Hilary Janks writes that texts "entice us into their way of seeing and understanding the world-into their version of reality," and adds that "language, together with other signs, works to construct reality" (61). This is to say that in children's literature, ideologies are frequently manifested multimodally, within intersections of images, words, and other textual features.

Because children's literature "remains a primary vehicle for intellectual and imaginative maturation" (Ghiso, Campano, and Hall 15), CMA posits that children's identities and realities are constructed-at least to some degreethrough their dialogic interactions with literary texts, contexts, and ideologies. In that vein, Perry Nodelman and Mavis Reimer write: "People are not always conscious of the ideologies that affect them. Or, to put it another way, they are not always conscious that the ideas are ideologies, and just assume them to be the way things obviously are ... Ideology works best by disappearing, so that people simply take their ideological assumptions for granted as the only, whole, and unquestionable truth" (80). By focusing my analysis on a specific text and the particular sociopolitical issues that are enacted within it, I aim to explore how its ideologies may be taken up by young readers in the process of constructing identities and realities. This pursuit is assisted in the knowledge 
that there are very few popular children's texts which deal with the divisive topic of school charterization. In spite of the "divergent, competing, and sometimes violently opposed ideologies" (Sutherland 143) that characterize school "reform" in the twenty-first century, young readers of Ultimate Comics SpiderMan are unlikely to encounter the subject in other children's media.

Over the past several decades, literacy scholars and educators have increasingly looked beyond word-centric print texts to consider multiple genres, modes, media, and a wider range of lived experiences within which children, youth, and adults make and express meanings (e.g., Hull and Nelson; New London Group) and perform hybrid identities (e.g., Cowan; Simon). Building from this research, a growing body of scholarship has emerged that is devoted to comics in the field of literacy education (e.g., Low; Pantaleo; Schwarz; Versaci). As Brian Tucker notes, the medium of comics forces readers to attend "not only to the stories but also to their discourse, to how comics constitute meaning in a way that is different from those of other media" (28). Comics is a uniquely visuo-textual medium existing somewhere "between telling and showing on the one hand, and concealing on the other" (Ghiso and Low 28), making it particularly rich for understanding children's multimodal enactments of literacy.

As polysemic texts which require readers to "marry print and visual representations in order to read in ways that are deeply meaningful" (Cromer and Clark 589), neither the visual nor the verbal mode may be given short shrift when analyzing inclusions and exclusions in comics texts. Thus, in looking at visuo-textual representations in Ultimate Comics Spider-Man, I will be using an assortment of analytic tools, drawing from picture book scholars, comics scholars, and multimodalities scholars-all through a critical lens-to assist in my meaning-making of Sara Pichelli's images. Critical visual analysis is concerned with how "visual resources are and can be mobilized to act and work on the viewer," and attempts to reveal images' "culturally and historically situated ideological implications" (Aiello 101). It is through this framework that I will undertake a close reading of Sara Pichelli's artwork and the ways in which it represents people, objects, and institutions. Additionally, I will apply critical discourse analysis to examine "the social and political significance" of Brian Michael Bendis's written dialogue (Fairclough 135).

The comics scholar Hillary L. Chute argues for the importance of placing images within a chapter "as the chapter unfolds," writing that in order to analyze comics, "one needs to be able to quote an image, just as in analyzing poetry one needs to be able to quote lines from a poem" (Graphic Women ix). I have similarly come to the decision - not lightly-that for the purpose of this analysis, I will isolate Bendis and Pichelli's panels from their original layout. Certainly, this decision sacrifices the "gestalt" of the page (Beaty and Nguyen 8; 
Versaci 102) by overlooking panel design and spatial features (as well as margins and gutters), but the panel-by-panel nature of my analysis necessitates such fragmentation. Further, Pichelli's artwork is presented here in grayscale, having been stripped of Justin Ponsor's colors. Readers interested in viewing the three-page sequence in its original form are encouraged to seek out Ultimate Comics Spider-Man \#1 or an anthologized edition of the title.

\section{Spider-Man Waits for Superman}

In a host of cities across the United States, charter schools have become an increasingly contentious topic during the past two decades. The march of urban charterization, as part of a larger market-driven neoliberal "reform" movement (LeBlanc 300) backed by the likes of Michelle Rhee, Geoffrey Canada, Bill Gates, and Michael Bloomberg, has won many followers while igniting pockets of fierce resistance. Proponents of charter schools laud greater school choice and a non-unionized teaching force as panaceas for educational iniquities (see Kirst for an overview), while critics see charterization as an essential ingredient-along with standardized testing tied to punitive school and teacher accountability measures-in the systematic dismantlement of public education (e.g., Karp; Ravitch, "Reign of Error"). The narrative perpetuated by pro-charter advocates is that "public schools, especially those in urban areas, are uniformly failing" and that "charter schools are the best solution to this problem" (Darling-Hammond and Lieberman 31). It has become a narrative that is well-trod in adult media to the point that the story of America's failing urban public schools has largely entered the realm of "common sense." As many scholars and educators draw attention to, however, the story is a fiction, or at least an exaggeration, "framed by half-truths and distortions" (DarlingHammong and Lieberman 32).

Many Americans became aware of the controversies surrounding the charter school movement with the wide release of the film Waiting for "Superman" in 2010, and its subsequent media frenzy. Davis Guggenheim's documentary tells the story of five families who are attempting to escape the "failed enterprise" of American public education (Ravitch, "Myth of Charter Schools" 19) and win lottery spots for their children in charter schools. The film purports to address issues of race in America-four of the five families featured are Black or Latin@-but without examining larger issues such as endemic poverty or inadequate school funding (Darling-Hammond and Lieberman 32). It has thus been argued that the pro-charter film "offers solutions that are simplified, ignore research evidence, and are built on false assumptions" (Dutro). Indeed, in a national study of 5,000 charter schools conducted by Stanford University's Hoover Institution, it was found that fewer than 17 percent achieved better 
results than matched public schools, while 37 percent yielded worse results and 46 percent showed no significant difference (Lubienski and Lubienski). These statistics have not seemed to slow the onslaught of new charters, however, nor have they significantly altered the perception that public schools are underperforming (Gallup). One wonders if the Superman of comic books and film rescued only 17 percent of people falling from Metropolis skyscrapers, how much longer he would retain the title of Superman. (And what if the numbers of fallers had been greatly exaggerated in the first place?)

It is a different iconic superhero to whom I now turn. If Superman is known as the defender of "truth, justice, and the American way," then Spider-Man is just as celebrated for his mantra that "with great power comes great responsibility," which feels uncannily appropriate for the enterprise of American education. In the pages that follow, I present a panel-by-panel critical visual analysis of the three-page sequence in Ultimate Comics Spider-Man \#1 depicting the Brooklyn Visions Academy lottery.

In the first issue of Ultimate Comics Spider-Man, before 11-year-old Miles Morales is bitten by the spider that will give him superpowers, he is taken by his parents to a charter school lottery not unlike those portrayed in Waiting for "Superman." The scene opens with an establishing shot of a bustling street in Brooklyn that is depicted as robustly multiracial and multigenerational.

Miles's family, introduced to the reader as they move from the background into the foreground, is similarly multiracial; his father, the puzzlingly named Jefferson Davis, is Black, ${ }^{3}$ and his mother, Rio Morales, is Puerto Rican. The White writer of the comic book series, Brian Michael Bendis, ${ }^{4}$ explained in an interview that his goal in creating Miles's family was to "write people outside of [his own] experience" in a way that readers would "recognize as the world around [them]" (Riesman). Certainly, a family walking down the street while arguing is not terribly difficult to identify with, irrespective of class, race, or ethnicity. Miles, wearing the number 2 on his shirt (i.e., the second SpiderMan), is the object of his parents' argument, but he is not provided his own voice in the initial panel.

In the second panel the focus shifts to Miles, pushing his parents and their surroundings momentarily outside the story world (Uspensky 137). The reader meets Miles at eye level, and his slightly turned gaze makes this, in effect, a child-centric "offer" image (Kress and van Leeuwen 381), directing the reader to enter into an empathetic kinship with him. Not incidentally, such kinship is a touchstone of quality children's literature. Miles's position in the panel suggests his centrality to the narrative and his parents' roles as supporting characters (Mikkonen), while his facial features convey a sense of quiet frustration. Although we do not see Rio and Jefferson's faces, the combative tone of the scene lingers from the previous panel and is conveyed via their clashing 


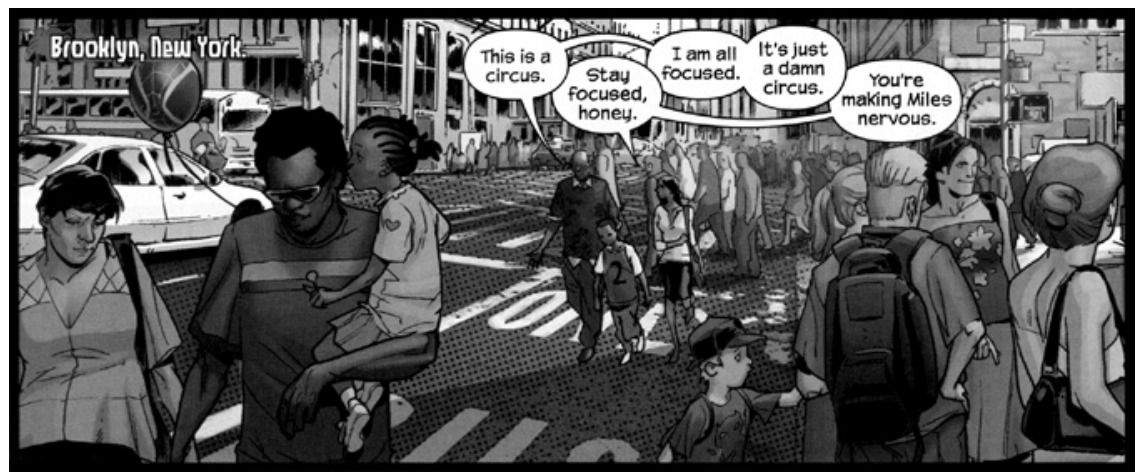

Fig. 18.1. Ultimate Comics Spider-Man \#1 by Bendis, Pichelli, and Ponsor (2011) 10.1.

(c) MARVEL. All rights reserved.

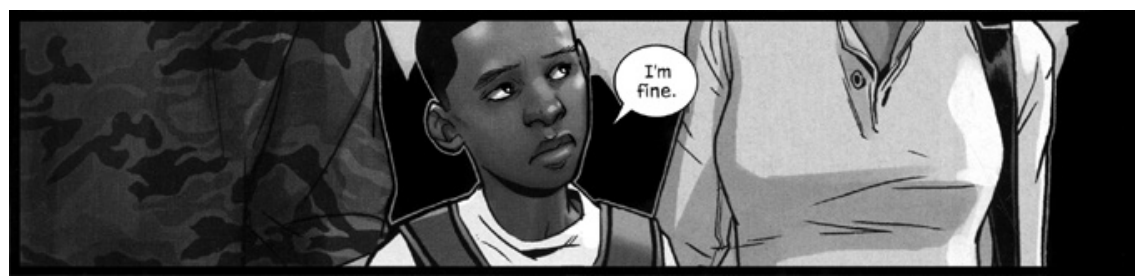

Fig. 18.2. Ultimate Comics Spider-Man \#1 by Bendis, Pichelli, and Ponsor (2011) 10.2.

(c) MARVEL. All rights reserved.

wardrobes. Caught between his mother in unyielding monochrome and his camouflage-clad father, Miles wears an athletic jersey, a player in a figurative game. As his father's camouflage fatigues suggest, Miles has entered the battleground of education "reform."

In panels 3 and 4 of the sequence (figure 18.3), Miles's mother lowers herself nearly to his level to explain the purpose of their day out. There is extensive visual and spatial information conveyed by Pichelli's figural placements within the panels: first, mother and son in profile, and then another "offer" image of Miles looking uncomfortable. Across the two panels, Pichelli employs several levels of contradictory focalization. The comics theorist Kai Mikkonen describes focalization (as it pertains to graphic narrative) as the set of visual and verbal elements which come together on a comics page-i.e., written language, speech balloons, illustrated characters, frames and gutters, etc.- that "interpenetrate each other and thus allow a multiplication of perspectives." Mikkonen explains that these interwoven elements, while inherently multiperspectival, may also "suggest a particular perspective in the story" (71). Thus, in spite of the fact that Rio's voice dominates Miles's in these panels (sixty-six words to his fifteen), Miles remains the focal point due to his being centered in 

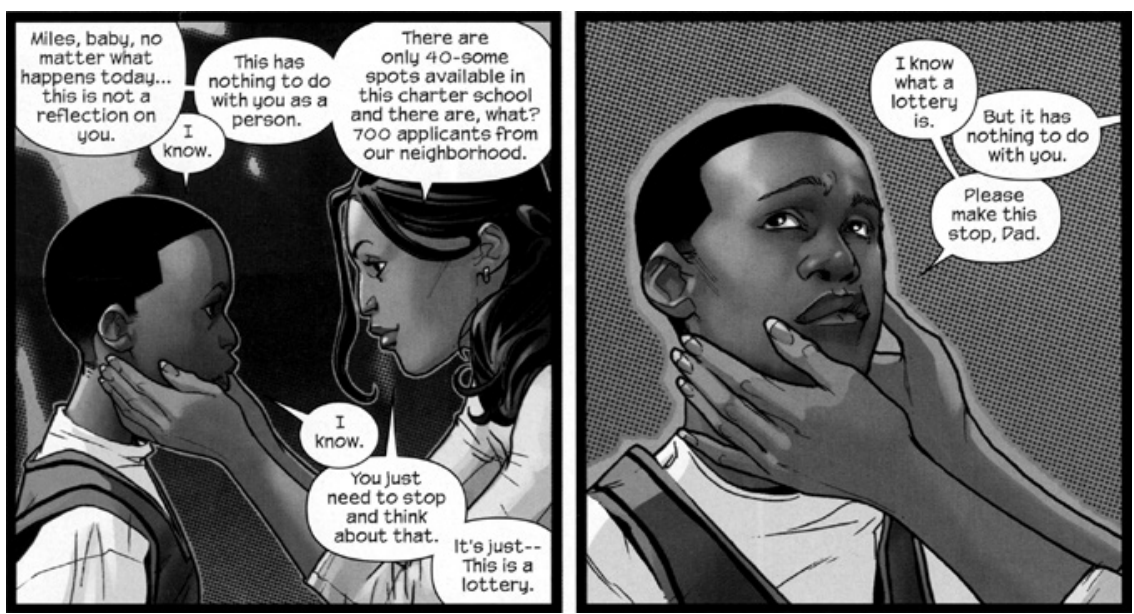

Fig. 18.3. Ultimate Comics Spider-Man \#1 by Bendis, Pichelli, and Ponsor (2011) 10.3-4.

(c) MARVEL. All rights reserved.

the right-hand panel. The reader is visually instructed to experience the scene first through Miles's perspective, then through Rio's. This focalization makes quite a bit of sense considering the comic book's intended audience of young readers.

In spite of Miles's visual prominence in figure 18.3, the text-heavy panels nevertheless direct the reader to construct a great deal of meaning from Rio's and Miles's actual dialogue (Golden and Gerber). Indeed, there is much exposition here. We learn what Jefferson had earlier referred to as "a damn circus": the school lottery event. Rio tells her son that it is unlikely he'll win admission to a charter school that denies roughly 94 percent of applicants from their neighborhood. This is a far cry from the Scantron test item's "open to all students" claim, and more in line with the 7 percent, 5 percent, and 4.5 percent chances that students had of winning a lottery spot in Waiting for "Superman." Still, neither Guggenheim's documentary nor Ultimate Comics Spider-Man seem to find fault with exclusionary tactics which, through structured admissions, are designed to keep test scores up by keeping "low-achieving," typically marginalized, students out (Bonastia; Darling-Hammond and Lieberman 35). Rather, the lottery is portrayed as a necessary if imperfect instrument for lucky families who are desperate to escape the perceived ruin of public education.

Through both her words and hand gestures, Rio attempts to mollify Miles by reassuring him that his rejection would not be reflective of him "as a person." The implication is that, should Miles fail to win a lottery spot and be forced to remain at his neighborhood school, it would not be a mark against him at an individual level. With only a few words, Rio indicates that 
Miles is better than his surroundings, reinforcing "an idea of community decay" (Campano 3) and Miles as the mythical "rose that grew from concrete" (Kirkland 74). The dialogue Bendis has written for Rio is indicative of the "culture of poverty" framework that has infiltrated popular discourses about urban schooling and which draws "from a longstanding U.S. tradition of viewing the poor from a deficit perspective" (Bomer, et al. 2500). This pervasive framework places the onus of poverty on the poor and connects class mobility with individual achievement that is rewarded through infusions of economic and social capital. It is the overarching "American dream" of freedom, meritocracy, and "rugged individualism ... which is part of our 'can do' national character" (Parini 53) - not too far off, as far as mythologies go, from Superman's commitment to American "truth" and "justice."

As Robert LeBlanc writes about how families are portrayed in Waiting for "Superman," the film's protagonists figure largely as "representations of the capitalist ideal: rugged, hardworking individuals who only wish to make a life for themselves." LeBlanc adds that such representations "perpetuate that fantasy that schools operate as islands from society, untouched by larger structural forces of inequality" (302). Indeed, nowhere in Rio's reassurance of her son does she suggest that poverty and inadequate funding of urban neighborhood schools are part of a larger systemic problem they should organize against, or that their community is a wonderful place to live, full of cultural and epistemological resources (Campano; González, Moll, and Amanti; Neill). Instead, Rio treats their community's perceived circumstances-deficient in comparison to some implicit "benchmark" of excellence (Spencer)—as a given, but not one that should make claims on Miles's identity. In Rio's words, Miles's community is "not a reflection" on him, and in fact, has "nothing to do" with him. In effect, Bendis's dialogue in figure 18.3 exemplifies Joyce E. King's concept of "dysconscous racism," or the perceptions, attitudes, and beliefs which reify inequality by "tacitly [accepting] dominant White norms" and overlaying them onto communities of color (135). In a bit of comic relief, Miles begs his father to "please make this stop."

In the sixth panel of the sequence (figure 18.4), the scene shifts in time and place to the auditorium holding the lottery event itself, which is nearly at its end. The auditorium is decorated as if for a joyous occasion-balloons in the shape of bell curves line the periphery-but tensions are high. With roughly 650 children vying for three remaining spots, it is surprising that anyone is able to remain seated at all. Pichelli's mise-en-scène, paired with Bendis's dialogue, establishes the relative distance between the conveners of the lottery and its contestants.

In the eighth overall panel of the sequence (top-right of figure 18.5), as Katie Hague wins the third-to-last spot at Brooklyn Visions Academy, Jefferson 


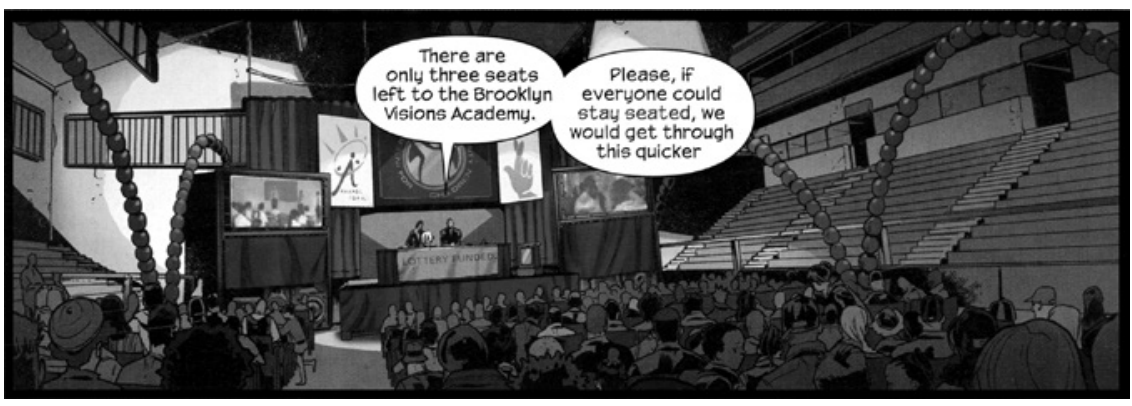

Fig. 18.4. Ultimate Comics Spider-Man \#1 by Bendis, Pichelli, and Ponsor (2011) 11.1.

(c) MARVEL. All rights reserved.
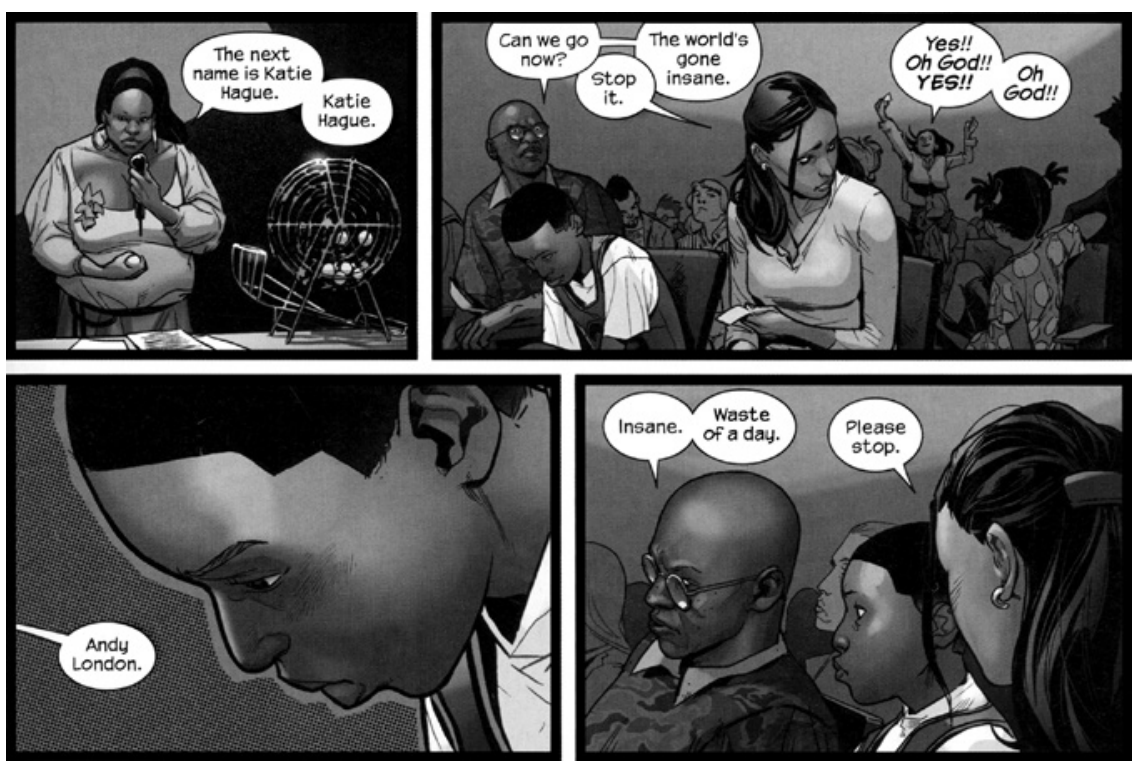

Fig. 18.5. Ultimate Comics Spider-Man \#1 by Bendis, Pichelli, and Ponsor (2011) 11.2-5.

(c) MARVEL. All rights reserved.

maintains the criticality he has held from the beginning of the scene. In saying that "the world's gone insane," Jefferson seems to understand how absurd this lottery ceremony truly is. It is unclear whether Jefferson's critique extends to the absurdity of school charterization itself-which, as some critics maintain, may actually widen gaps and reproduce inequalities between middle class and poor students (e.g., Bonastia; Cooper and Jordan; Darder)—or if it refers only to the lottery event and the fervor it has fomented. Surely, there is some visual cruelty in employing a gaming device ("Bingo!") to determine the opportunities of children. 

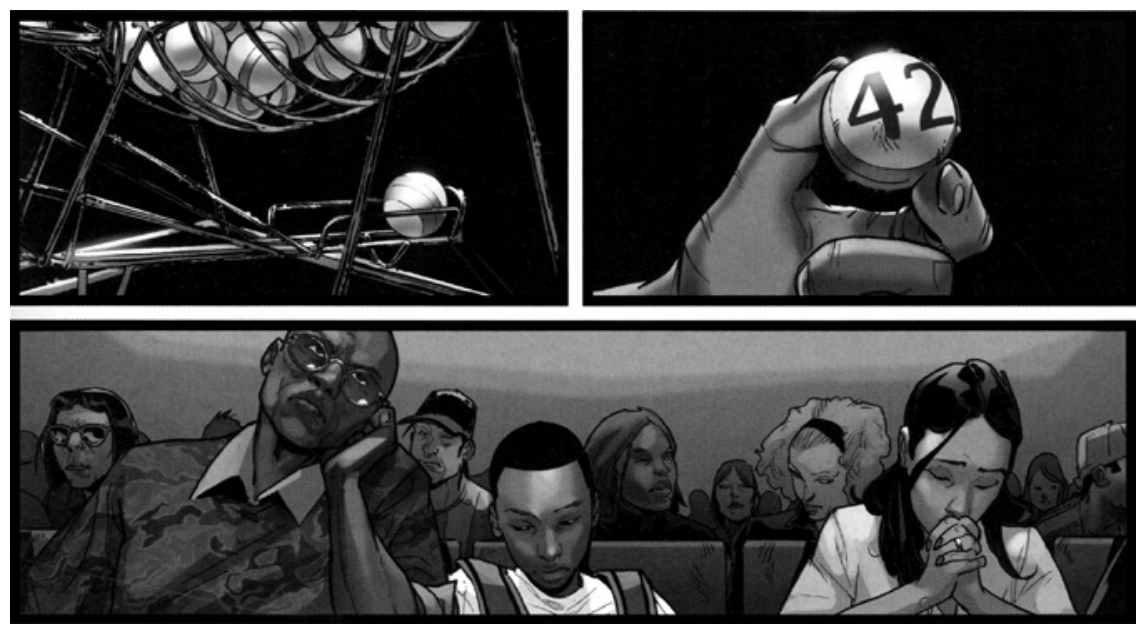

Fig. 18.6. Ultimate Comics Spider-Man \#1 by Bendis, Pichelli, and Ponsor (2011) 11.6-8.

(c) MARVEL. All rights reserved.

Behind the Morales family, the Hagues celebrate their good fortune by invoking a higher power and leaping from their seats. Rio looks discernibly uncomfortable, asking Jefferson to shelve his cynicism, while Miles wordlessly stares at the floor. Panels 9 and 10 of the lottery sequence (the bottom two panels of figure 18.5) mainly reiterate what's preceded them. Visually, panel 9's close-up of Miles from a slight overhead view reemphasizes his dejection and powerlessness as Andy London's name is called (Sipe 71). Verbally, Jefferson reiterates his critique while Rio again implores him to stop. To this point, Miles's parents' disagreement about attending the lottery has been one of the consistent narrative through-lines of the sequence.

Near the bottom of the lottery sequence's second page, the moment arrives, delivering the final ball that will, to some degree, determine Miles Morales's future. The panels in figure 18.6 are visually quite interesting without containing a single word. In the first panel, the ball of destiny rolls along its track, building up narrative tension as it does. In the next panel, the ball-emphasized in extreme close-up for dramatic effect (Schieble 50)-seems to be illuminated from above, as if by some celestial force, not unlike the child on the movie poster for Waiting for "Superman." I am reminded of an episode of The Simpsons in which Homer looks to the heavens and beseeches, "I'm not normally a praying man, but if you're up there, please save me, Superman!" The third panel shows that Rio is in fact praying as Miles looks bored and Jefferson looks irritated. But back to Miles, and his "wait for Superman." Call it luck, destiny, or divine intervention. Whatever the case may be, the Morales family will be sending their son to Brooklyn Visions Academy in the fall. But they do not know it yet. 

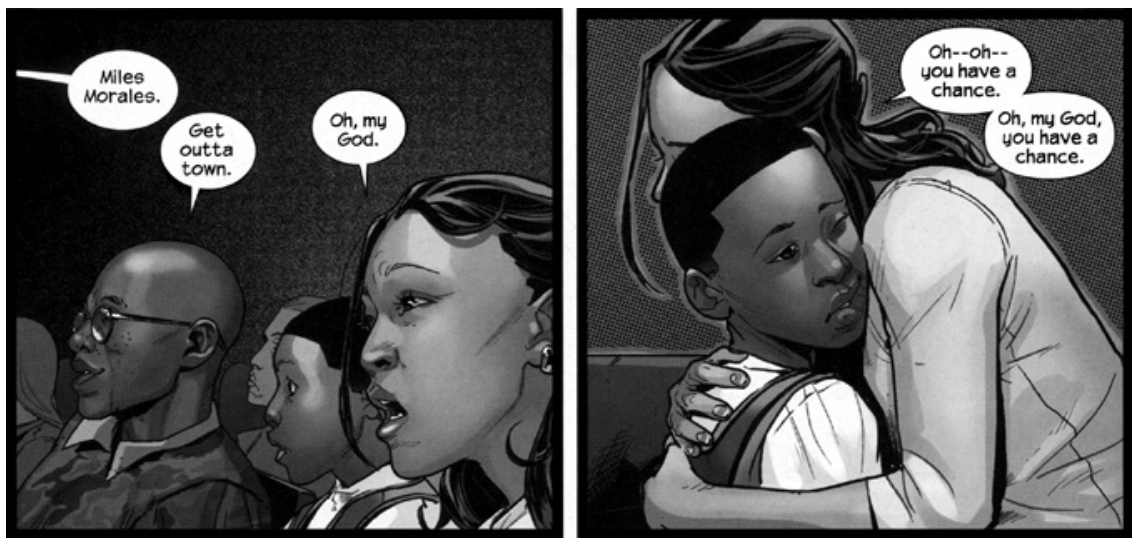

Fig. 18.7. Ultimate Comics Spider-Man \#1 by Bendis, Pichelli, and Ponsor (2011) 12.1-2.

(c) MARVEL. All rights reserved.

The color palette used to illustrate these scenes further augments a message of deliverance. Pichelli's lottery ball operates as a white orb held aloft in a sea of blackness, which could certainly be read to take on racial overtones (Schieble 50). In this vein, the number 42 is itself interesting for several culturally specific reasons. At the surface level of the story, there is a parallel between the lottery ball and the arachnid (specimen \#42) that will eventually envenomate Miles. Beyond the interior world of the story, the number 42 likely alludes to the jersey number worn by Jackie Robinson, who, as a member of the Brooklyn Dodgers, became the first African American man to play Major League Baseball in the twentieth century. The number 42 has been reverentially retired by every MLB team and holds special meaning at the intersection of race and popular culture. While Miles is not the first mainstream comic book character to have broken the "color barrier," he is among the most highprofile $(\mathrm{Fu})$. Having a mixed-race child take on the mantle of Marvel's most recognizable character, while not a perfect analogy to Jackie Robinson, feels like an apt homage to both Brooklyn and \#42..$^{5}$

Atop a new page, Miles's name is announced, and for the first time, Jefferson cracks a smile. It is interesting how quickly his affect changes once his son's name is called. No longer visibly irritated, it seems Jefferson ceases to reject the lottery once his family has benefited from it. Rio, meanwhile, invokes the deity she had prayed to in the previous panel. In the right-hand panel of figure 18.7, secure in her knowledge that Miles will be attending a charter school, Rio tells her son that now he has a chance. The disturbing implication of this utterance is that had Miles not won a lottery spot, he would not have had a chance, presumably, to succeed in life; that an urban public education is tantamount to utter catastrophe. It is more or less the story told by Waiting for "Superman" 

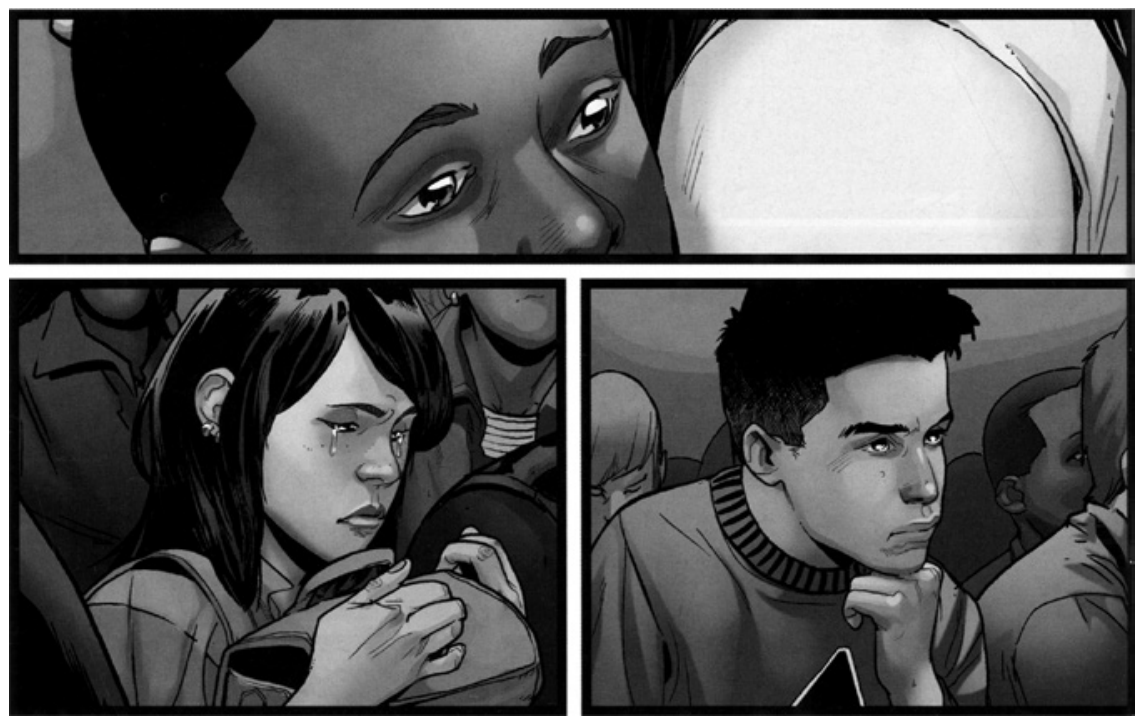

Fig. 18.8. Ultimate Comics Spider-Man \#1 by Bendis, Pichelli, and Ponsor (2011) 12.3-5.

(c) MARVEL. All rights reserved.

and a host of corporate education "reformers." And in spite of being both factually inaccurate and effectively pathologizing communities of color, it is a story that persists in the world outside of comics.

Following Miles's lottery win, Pichelli curates a powerful visual sequence, wordlessly illustrating some of the "losers" of the day below Miles's remorseful gaze. Through three "offer images," the reader feels the gravity of the events which, while ostensibly benefiting Miles, are necessarily harming others. Pichelli's images express the social injustice that is perpetuated when not every student's education is equitably funded. Simultaneously, and keeping with the undercurrent of the entire sequence, Pichelli's drawings also serve to re-inscribe the popular opinion that public schools are failing their "at-risk" students, while charter schools are the rescuer of America's poor urban children. The tears of the girl on the bottom-left echo Geoffrey Canada's opening narration from Waiting for "Superman": "One of the saddest days of my life was when my mother told me Superman did not exist... [I cried] because no one was coming with enough power to save us" (Guggenheim). Unexamined here is that "Superman" is a facile symbol for the type of savior complex which "supports brutal policies in the morning, founds charities in the afternoon, and receives awards in the evening" (Cole).

The nineteenth and final panel of the school lottery sequence (figure 18.9) reemphasizes the themes of neoliberal "reform" that have been undergirding the entire scene. Foremost, the tenet of individualism rises to the surface 

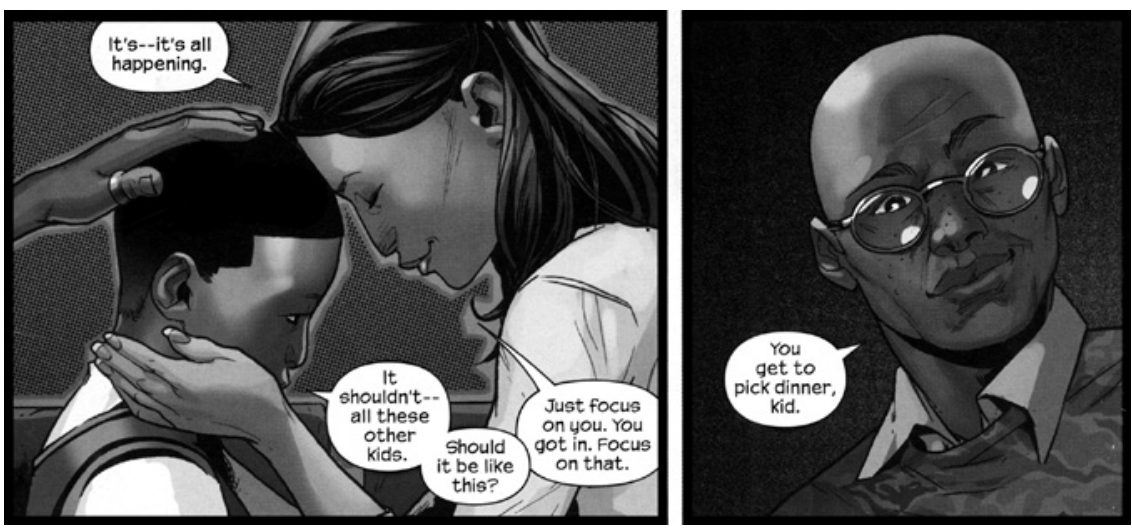

Fig. 18.9. Ultimate Comics Spider-Man \#1 by Bendis, Pichelli, and Ponsor (2011) 12.6.

(c) MARVEL. All rights reserved.

with Rio's counsel to "just focus on you," in spite of Miles's feelings of guilt. Miles, thinking of the "other kids" who were not as lucky as him, and asking "Should it be like this?" seems to endorse a communitarian ethos of interdependence, of mutuality (Ghiso) - that nobody wins unless everybody wins. Rio, on the other hand, endorses the competitive ethos of capitalism that is concomitant with a neoliberal ideology: individual advancement is placed above the well-being of community. In Analysing Discourse, Norman Fairclough writes that the "textual process of meaning-making is an important element in the political process of [achieving] hegemony for neoliberalism in so far [sic] as it contributes to building up a vision of the "new age" (101). That is, Rio's words (i.e., Bendis's dialogue) matter. They contribute to the construction of Miles's (i.e., readers') reality (Janks 61). The message in this three-page sequence is clear: In order to attend a "better" school and to succeed in life, children, and especially urban children of color, must escape their neighborhood schools and focus on competitive individual achievement (defined by White middleclass knowledge norms) at the expense of community commitments. This message has been disseminated by corporate "reformers" for the past two decades as their programs drain public funds from public schools and channel the money into private for-profit institutions. While Miles, through Bendis, questions this hegemonic message, it is ineffectual; his ultimate matriculation at Brooklyn Visions Academy does not sufficiently challenge the juggernaut of market-based education "reform" nor question its "common sense" assumptions. As Nodelman and Reimer warn us (vis-à-vis the messages in children's literature): "Ideology works best by disappearing, so that people simply take their ideological assumptions for granted as the only, whole, and unquestionable truth" (80). 
Assessment researcher Jamal Abedi, responding to the pro-charter Scantron test item which opened this chapter, argued that without offering an opposing viewpoint, "Poor kids might feel bad when reading it. Kids not in charters may feel bad ... Taking the side of charter schools is not appropriate" (quoted in Rossi). Herein lies the danger of a popular text like Ultimate Comics SpiderMan's portrayal of a charter school lottery in an urban neighborhood. It is the danger of perpetuating for children only a single story of education "reform" in the United States. As Chimamanda Ngozi Adichie argues in her 2009 TED Talk, we are "impressionable and vulnerable in the face of a story, particularly as children" (Adichie). Without access to multiple stories and a plenitude of counterpoints, children must make do with limited quantities of literature and other media dealing with the contemporary political issues that affect them most intimately. Patricia Enciso writes that children often "have only mainstream culture to refer to as a source of explanation for the fictional and actual events they encounter," and adds that, as readers, how young people "make sense of fictional encounters has a significant bearing on how [they] learn to make sense of the real world" (527). The authors of fictional encounters must therefore recognize their great power and take responsibility for it.

American children and youth in the early twenty-first century-and urban students of color in particular-are forced to navigate an ideological battlefield while attending school. The field has been drawn and is mediated by adults coming from a range of political camps, but young people are the ones pushed into the trenches. As I argue at the beginning of this chapter, contemporary education "reform," as an issue that affects the lives of so many students, should not be elided as a topic in which children are afforded agency and criticality. Rather, young readers should be provided many opportunities to engage a range of views, words, and images about the schooling systems to which they are part and parcel. This is one of the central goals and responsibilities of highquality children's literature. As my late professor Larry Sipe was fond of saying, a chief purpose of literature is to de-familiarize life, to challenge our comfortable assumptions, and to jar us awake.

Through the medium's inherent multiperspectivity, comics have the potential to destabilize "common sense" ideologies and single-story narratives (e.g., Horstkotte and Pedri; Mikkonen). The creators of comics for young readers should thus emphasize their medium's historically "countercultural function that rebuffs adult efforts to shape children's memories, identities, and tastes" (Hatfield and Svonkin 434) by creating work that stimulates critical multimodal readings. In order to do this, comics texts produced for an audience of young people should represent a robust diversity of identities, opinions, and 
experiences (e.g., Mohanty). To paraphrase Beverly Slapin, "issues-based" children's literature does not have to present a "sociological treatise" in order to be of high quality. Simply put, literature "should be honest in its depictions" and invite readers to critically engage topics from a variety of perspectives (Slapin). This is not accomplished when inaccuracies and half-truths are presented as fact. The multimodal medium of comics, which is "structurally equipped to challenge dominant modes of storytelling" (Chute, "Comics as Literature" 456), is ideal for encouraging critical engagement around contested political topics (Carleton). And because comics and graphic novels are currently so popular with young readers in and out of school (Low and Campano; Simon), they should absolutely be employed to invite children to think more deeply, in more complicated and nuanced ways, about contemporary issues such as education "reform."

Employing a hybrid approach to critical multicultural analysis and critical multimodal analysis, I have attempted to make visible the ways in which Bendis's writing and Pichelli's illustration-as part of a three-page sequence on urban school charterization-contribute to dominant education "reform" discourses that have been ubiquitous in America during the opening decades of the twenty-first century. ${ }^{6}$ Their discursive ubiquity, as I have previously mentioned, is mostly limited to adult media, which tend to provide a wider range of counterpoints. Children's media do not typically match adult-geared media in this commitment to balance, leaving young readers a narrower spectrum through which to engage contemporary topics like school "reform." As Kathleen O'Neil writes, children's literature today "continues to be a vehicle for cultural reproduction" (41), and the messages in it thus have the potential to profoundly influence the lives of young readers. For this reason, we simply cannot allow a debate as controversial and important as the one currently ripping through America's education system to become so one-sided in its children's media portrayals that it amounts to an invisible, an uncritical-and perhaps most catastrophically, an inevitable-ideology.

\section{Notes}

1. The young adult novel featuring a charter school is Lauren Barnholdt's Four Truths and a Lie from 2008. The issue of Time Magazine for Kids dealing with charter schools-credited to author Melanie Kletter-was released on September 13, 2013.

2. In May 2014, Ultimate Comics Spider-Man was relaunched as Miles Morales: The Ultimate Spider-Man. The book's continuity was unaffected by the title change, and Bendis continued as author. In February 2016, Miles joined the "mainstream" Marvel universe in Spider-Man \#1, which reunited the original creative team of Bendis, Pichelli, and Ponsor. Under the three titles, over forty issues of Miles's story have gone to press since 2011.

3. It is unclear why Bendis would name a Black character "Jefferson Davis" (i.e., the White, slave-owning president of the Confederacy during the American Civil War). It is certainly an 
odd symbol for a title that touches on issues of race and opportunity, and I am unable to locate any source in which Bendis explains his decision.

4. Brian Michael Bendis is one of the most prolific and popular writers working in the comics industry today. In addition to Ultimate Spider-Man (which he has been writing consistently since 200o), Bendis has worked on Marvel's X-Men, Daredevil, and Avengers properties. He is also known for creator-owned series such as Powers and Torso.

5. In addition to Jackie Robinson's jersey, to fans of Douglas Adams's The Hitchhiker's Guide to the Galaxy, the number 42 refers to "the Answer to the Ultimate Question of Life, the Universe, and Everything." Unfortunately, as with school reform, no one quite knows what the question is.

6. Moving ahead in the series, Miles's educational experiences at Brooklyn Visions Academy are not a major element of Ultimate Comics Spider-Man, which, in general, is a very good comic book series. Nevertheless, the three-page sequence reviewed in this chapter is important to parse in order to understand Bendis's outlook toward his characters and their setting. It helps situate the series within hegemonic "culture of poverty" discourses, even when Bendis is critical of certain institutions that emerge from within those discourses.

\section{Works Cited}

Adichie, Chimamanda Ngozi. “The Danger of a Single Story.” TED Global. Oxford, UK. July 2009. Web.

Aiello, Giorgia. "Theoretical Advances in Critical Visual Analysis: Perception, Ideology, Mythologies, and Social Semiotics." Journal of Visual Literacy 26.2 (2006): 89-102. Print.

Beaty, Bart, and Nick Nguyen. "Foreword." The System of Comics. Thierry Groensteen. Trans. Bart Beaty and Nick Nguyen. Jackson, MS: University Press of Mississippi, 2007. vii-x. Print.

Bendis, Brian Michael, and Sara Pichelli. Ultimate Comics Spider-Man. Vol. 1. New York: Marvel, 2012. Print.

Bomer, Randy, Joel E. Dworin, Laura May, and Peggy Semingson. "Miseducating Teachers About the Poor: A Critical Analysis of Ruby Payne's Claims about Poverty." Teachers College Record 110.12 (2008): 2497-531. Print.

Bonastia, Christopher. "Why the Racist History of the Charter School Movement Is Never Discussed." National Public Voice, 9 March 2012. Web.

Botelho, Maria José, and Masha Kabakow Rudman. Critical Multicultural Analysis of Children's Literature: Mirrors, Windows, and Doors. New York: Routledge, 2009. Print.

Campano, Gerald. Immigrant Students and Literacy: Reading, Writing, and Remembering. New York: Teachers College Press, 2007. Print.

Carleton, Sean. "Drawn to Change: Comics and Critical Consciousness." Labour/Le Travail 73 (2014): 151-77. Web.

Cavna, Michael. "Miles Morales and Me: Why the New Biracial Spider-Man Matters." The Washington Post, 4 August 2011. Web.

Chute, Hillary, L. "Comics as Literature? Reading Graphic Narrative." PMLA 123.2 (2008): 452-65. Print.

Graphic Women: Life Narrative and Contemporary Comics. New York: Columbia University Press, 2010. Print.

Cole, Teju. "The White-Savior Industrial Complex." The Atlantic, 21 March 2012. Web.

Connors, Sean P. "Toward a Shared Vocabulary for Visual Analysis: An Analytic Toolkit for Deconstructing the Visual Design of Graphic Novels." Journal of Visual Literacy 31.1 (2012): 71-92. 
Cooper, Robert, and Will J. Jordan. "Cultural Issues in Comprehensive School Reform." Educating Black Males: Voices from the Field. Ed. Olatokunbo S. Fashola. Washington DC: Brookings Institution Press, 2005. 1-18. Print.

Cowan, Peter. "'Drawn' into the Community: Re-Considering the Artwork of Latino Adolescents." Visual Sociology 14 (1999): 91-107. Print.

Cromer, Michael, and Penney Clark. "Getting Graphic with the Past: Graphic Novels and the Teaching of History". Theory and Research in Social Education 35.4 (2007): 574-91.

Darder, Antonia. "Racism and the Charter School Movement: Unveiling the Myths." TruthOut, 30 November 2014. Web.

Darling-Hammond, Linda, and Ann Lieberman. “Educating Superman." Finding Superman: Debating the Future of Public Education in America. Ed. Watson Scott Swail. New York: Teachers College Press, 2012. 31-45. Print.

Dutro, Elizabeth. "Review of Waiting for 'Superman." National Education Policy Center. 24 January 2011. Web.

Enciso, Patricia. "Cultural Identity and Response to Literature: Running Lessons from Maniac Magee." Language Arts 71.6 (1994): 524-33. Print.

Fairclough, Norman. Analysing Discourse: Textual Analysis for Social Research. London: Routledge, 2003. Print.

Foster III, William H. Looking for a Face Like Mine: The History of African Americans in Comics. Waterbury CT: Fine Tooth Press, 2005. Print.

Fraser, Ryn. "Ultimate Comics Spider-Man Sales Figures." World of Black Heroes. 11 February 2012. Web.

Fu, Albert S. "Fear of a Black Spider-Man: Racebending and the Colour-Line in Superhero (Re) casting." Journal of Graphic Novels and Comics 6.3 (2015): 269-83. Print.

Gallup Poll of Historical Trends in Education. Gallup, 2013. Web.

Ghiso, María Paula. "The Laundromat as the Transnational Local: Young Children's Literacies of Interdependence." Teachers College Record 118.1 (2016): 1-46. Print.

Ghiso, María Paula, and David E. Low. "Students Using Multimodal Literacies to Surface Micronarratives of United States Immigration." Literacy 47.1 (2013): 26-34. Print.

Ghiso, María Paula, Gerald Campano, and Ted Hall. "Braided Histories and Experiences in Literature for Children and Adolescents." Journal of Children's Literature 38.2 (2012): 14-22. Print.

Golden, Joanne M., and Annyce Gerber. "A Semiotic Perspective of Text: The Picture Story Book Event." Journal of Reading Behavior 22.3 (1990): 203-19. Print.

González, Norma, Luis C. Moll, and Cathy Amanti. Funds of Knowledge: Theorizing Practices in Households, Communities, and Classrooms. Mahwah NJ: Lawrence Erlbaum Associates, 2005. Print.

Hatfield, Charles, and Craig Svonkin. "Why Comics Are and Are Not Picture Books: Introduction." Children's Literature Association Quarterly 37.4 (2012): 429-35. Print.

Horstkotte, Silke, and Nancy Pedri. "Focalization in Graphic Narrative." Narrative 19.3 (2011): 330-57. Print.

Hull, Glynda A., and Mark Nelson. "Locating the Semiotic Power of Multimodality." Written Communication 22.2 (2005): 224-61. Print.

Hyde Park Johnny. “Chicago Schools Caught Brainwashing Students." Daily Kos. 27 May 2012. Web.

Janks, Hilary. Literacy and Power. New York: Routledge, 2010. Print.

Karp, Stan. "Charter Schools and the Future of Public Education." Rethinking Schools 28.1 (2013): 42-47. Print. 
King, Joyce E. “Dysconscious Racism: Ideology, Identity, and the Miseducation of Teachers." Journal of Negro Education 60.2 (1991): 133-46. Print.

Kirkland, D. E. “'The Rose That Grew from Concrete': Postmodern Blackness and New English Education. English Journal 97.5 (2008): 69-75. Print.

Kirst, Michael W. "Politics of Charter Schools: Competing National Advocacy Coalitions Meet Local Politics." Peabody Journal of Education 82.2-3 (2007): 184-203. Print.

Kress, Gunther, and Theo van Leeuwen. "Representation and Interaction: Designing the Position of the Viewer." The Discourse Reader. Ed. Adam Jaworski and Nikolas Coupland. London and New York: Routledge, 1999. Print.

LeBlanc, Robert. "Reform, Ideology and the Politics of Waiting for 'Superman." Power and Education 2.3 (2010): 300-308. Web.

Low, David E. "Spaces Invested with Content': Crossing the 'Gaps' in Comics with Readers in Schools." Children's Literature in Education 43.4 (2012): 368-85. Print.

Low, David E., and Gerald Campano. "The Image Becomes the Weapon: New Literacies and Canonical Legacies." Voices from the Middle 21.1 (2013): 26-31. Print.

Lubienski, Sarah Theule, and Christopher Lubienski. "School Sector and Academic Achievement: A Multi-Level Analysis of NAEP Mathematics Data." American Educational Research Journal 43.4 (2006): 651-98. Print.

McWilliams, Ora C. "Who Is Afraid of a Black Spider(-Man)?" Transformative Works and Cultures 13 (2013): n.p. Web.

Mikkonen, Kai. "Focalisation in Comics: From the Specificities of the Medium to Conceptual Reformulation." Scandinavian Journal of Comic Art 1.1 (2012): 69-95. Print.

Mohanty, Satya P. “The Epistemic Status of Cultural Identity: On Beloved and the Postcolonial Condition." Reclaiming Identity: Realist Theory and the Predicament of Postmodernism. Ed. Paula M. L. Moya and Michael R. Hames-García. Berkeley: University of California Press, 2000. 29-66. Print.

Nama, Adilfu. Super Black: American Pop Culture and Black Superheroes. Austin: University of Texas Press, 2011. Print.

Neill, Monty. “Don’t Mourn, Organize!” Rethinking Schools 18.1 (2003). Web.

New London Group. “A Pedagogy of Multi-Literacies: Designing Social Futures.” Harvard Educational Review 66.1 (1996): 60-92. Print.

Nodelman, Perry, and Mavis Reimer. The Pleasures of Children's Literature. 3 rd ed. Boston: Allyn and Bacon, 2003. Print.

O’Neil, Kathleen. “Once Upon Today: Teaching for Social Justice with Postmodern Picturebooks." Children's Literature in Education 41.1 (2010): 40-51. Print.

Pantaleo, Sylvia. "Reading Images in Graphic Novels: Taking Students to a 'Greater Thinking Level." English in Australia 49.1 (2014): 38-51. Web.

Parini, Jay. "The American Mythos." Daedalus 141.1 (2012): 52-60. Print.

Ravitch, Diane. "The Myth of Charter Schools." Finding Superman: Debating the Future of Public Education in America. Ed. Watson Scott Swail. New York: Teachers College Press, 2012. 19-30. Print.

. Reign of Error: The Hoax of the Privatization Movement and the Danger to America's Public Schools. New York: Alfred A. Knopf, 2013. Print.

Riesman, Abraham. "Sexism and Making a Nonwhite Spider-Man." Vulture, 1 May 2014. Web. Rossi, Rosalind. "Question Criticized as Charter-School 'Propaganda' Pulled from CPS Tests." Chicago Sun-Times, 25 May 2012. Web.

Schieble, Melissa. "Reading Images in American Born Chinese through Critical Visual Literacy." English Journal 103.5 (2014): 47-52. Print. 
Schwarz, Gretchen. “Expanding Literacies through Graphic Novels.” English Journal 95.6 (2006): 58-64. Print.

Siegel, Marjorie, and Carolyn P. Panofsky. "Designs for Multimodality in Literacy Studies: Explorations in Analysis." National Reading Conference Yearbook 58.1 (2009): 99-111. Print. Simon, Rob. "Without Comic Books, There Would Be No Me': Teachers as Connoisseurs of Adolescents' Literate Lives." Journal of Adolescent \& Adult Literacy 55.6 (2012): 516-26. Print.

Sipe, Lawrence R. "Learning the Language of Picturebooks." Journal of Children's Literature 24.2 (1998): 66-75. Print.

Slapin, Beverly, with Allyson Criner Brown. "Smoky Night by Eve Bunting: Misguided Effort to Help Kids Understand Rodney King Events.” Teaching for Change, 17 May 2012. Web.

Spencer, Tamara. "Learning to Read in the Wake of Reform: Young Children's Experiences with Scientifically Based Reading Curriculum." Perspectives on Urban Education 8.2 (2011): 41-50. Web.

Sutherland, Robert D. "Hidden Persuaders: Political Ideologies in Literature for Children." Children's Literature in Education 16.3 (1985): 143-57. Print.

Tucker, Brian. "Gotthold Ephraim Lessing's Laocoön and the Lessons of Comics." Teaching the Graphic Novel. Ed. Stephen E. Tabachnik. New York: The Modern Language Association of America, 2009. 28-35. Print.

Uspensky, Boris. A Poetics of Composition: The Structure of the Artistic Text and Typology of a Compositional Form. Trans. Valentina Zavarin and Susan Wittig. Berkeley and Los Angeles: University of California Press, 1973. Print.

Versaci, Rocco. "Literary Literacy' and the Role of the Comic Book: Or, 'You Teach a Class on What?" Teaching Visual Literacy: Using Comic Books, Graphic Novels, Anime, Cartoons, and More to Develop Comprehension and Thinking Skills. Ed. Nancy Frey and Douglas Fisher. Thousand Oaks, CA: Corwin Press, 2008. 91-111. Print.

Waiting for "Superman." Dir. Davis Guggenheim. Paramount Vantage, 2010. Film. 